\title{
Performance of Baby Corn (Zea Mays L.) in Integration of Organic and Inorganic Nitrogen
}

\author{
Bonani Bhattacharjee Tithi ${ }^{1}$, Mrityunjoy Biswas ${ }^{1,2, *}$, Palash Mandal ${ }^{1}$, MNH Miah $^{1}$, AP Chowdhury $^{1}$ \\ ${ }^{1}$ Department of Agronomy and Haor Agriculture, Sylhet Agricultural University (SAU), Bangladesh \\ ${ }^{2}$ Department of Agro Product Processing Technology, Jashore University of Science and Technology, Bangladesh
}

Copyright $\bigcirc 2019$ by authors, all rights reserved. Authors agree that this article remains permanently open access under the terms of the Creative Commons Attribution License 4.0 International License

\begin{abstract}
Nitrogen (N) fertilization mostly determines the productivity of a crop. The supply of $\mathrm{N}$ can be ensured in both inorganic and organic means. Slowly released organic $\mathrm{N}$ can be combined with inorganic $\mathrm{N}$ to minimize the detrimental effect of chemical fertilizers to environment as well as to ensure the sustainable production. To observe the response of baby corn in integration of organic and inorganic $\mathrm{N}$ field experiments were conducted in $\mathrm{N}$ deficit soil in consecutive winter and summer. There were five nutrient levels as treatment in the experiment. The treatments used in the winter season were $\mathrm{T}_{1}=\mathrm{N} 0 \mathrm{~kg}+$ CD $15 \mathrm{tha}^{-1}, \mathrm{~T}_{2}=\mathrm{N} 60 \mathrm{~kg}+\mathrm{CD} 15 \mathrm{tha}^{-1}, \mathrm{~T}_{3}=\mathrm{N} 90 \mathrm{~kg}+\mathrm{CD}$ $10 \mathrm{tha}^{-1}, \mathrm{~T}_{4}=\mathrm{N} 120 \mathrm{~kg}+\mathrm{CD} 5 \mathrm{t} \mathrm{ha}^{-1}$ and $\mathrm{T}_{5}=\mathrm{N} 150 \mathrm{~kg}+$ CD $0 \mathrm{t} \mathrm{ha}^{-1}$ while in the summer season $\mathrm{T}_{1}=\mathrm{N} 30 \mathrm{~kg}+\mathrm{CD}$ $15 \mathrm{t} \mathrm{ha}^{-1}$ varied and others remained same as in the winter season. The lowest cob yield without husk was found where minimum inorganic $\mathrm{N}$ was combined with organic $\mathrm{N}$ in both seasons. Plant received only $\mathrm{N}$ from inorganic source represented highest cob yield. Statistically similar yield was also obtained from one combination of inorganic and organic $\mathrm{N}\left(120 \mathrm{~kg} \mathrm{~N}+5\right.$ ton $\left.\mathrm{CD} \mathrm{ha}^{-1}\right)$, where the rate of inorganic $\mathrm{N}$ was $20 \%$ lower than that of sole inorganic $\mathrm{N}$ source. Between seasons, significantly positive yield response was recorded in winter irrespective of nutrient levels. Therefore, one fifth of inorganic $\mathrm{N}$ application can be minimized in terms of integrated $\mathrm{N}$ management from organic and inorganic sources without affecting potential yield of baby corn.
\end{abstract}

Keywords Baby Corn, Organic and Inorganic N, Growth, Yield

\section{Introduction}

Maize (Zea mays L) is the third most important cereal crop next to rice and wheat (Mahmoodi \& Rahimi [23]) and has the highest production potential among the cereals. Maize, being a $\mathrm{C} 4$ plant, able to adapt in an adverse climatic condition such as high temperature, drought, elevated $\mathrm{CO}_{2}$ and can efficiently convert absorbed nutrients into food (Lara \& Andreo [20]; Archana \& Bai [3]). For diversification and value addition of maize as well as growth of food processing industries, recent development is of growing maize for vegetable purpose, which is commonly known as 'baby corn'. It is dehusked young cob of maize harvested at the silk stage (Kumar \& Bohra [19]). The high-nutritive value, eco-friendly and crispy nature of baby corn have made it a special choice for various traditional and continental dishes apart from canning in the elite society. It has higher nutritive value, reported that $100 \mathrm{~g}$ of baby corn contained $89.1 \%$ moisture, $0.2 \mathrm{~g}$ fat, $1.9 \mathrm{~g}$ protein, $8.2 \mathrm{mg}$ carbohydrate, $0.06 \mathrm{~g}$ ash, $28.0 \mathrm{mg}$ calcium, $86.0 \mathrm{mg}$ phosphorus and $11.0 \mathrm{mg}$ of ascorbic acid (Thavaprakaash et al. [28]; Das et al. [8]).

Yield and quality of baby corn are affected by cultural management applied to the maize crops especially fertilizer application (Lone et al. [21]). Nitrogen is the most important nutrient for the growth and yield of corn (Henrique Demari et al. [17]). The application of chemical fertilizer may assist in obtaining maximum production of baby corn but keeping in mind that chemical fertilizer may lead to hazardous effect on environmental health besides increasing production cost as such the judicious uses of fertilizers from different source will maintain the environmental health and sustainability (Dadarwal [7]). Besides, organic agricultural products becoming more popular to the consumers considering health environmental benefit (Muhammad et al. [24]). The practice of organic sources helps to uphold soil physical, chemical, and microbiological properties of soil (Timsina [30]). The energy crisis, environmental degradation and hike in prices of the inorganic fertilizers necessitate the use of organic $\mathrm{N}$ in crop production. However, $\mathrm{N}$ mineralization from organic sources slow enough to restrict potential uptake of $\mathrm{N}$ for corn especially early part of growing season and reduce yield (Pang \& Letey [26]). Not only depending fully inorganic or organic $\mathrm{N}$ source, the sustainability in crop 
production and soil health can be achieved through integrated nutrient management (Dawe et al. [9]). In addition, $\mathrm{N}$ mineralization and requirement of corn depends on growing season. Because the key machine of mineralization process are soil microbes (bacteria, fungi, and actinomyces) and their activity depends on seasonal variable soil temperature, water content and aeration (Kitchen \& Goulding [18]). Therefore, this study was designed to investigate the suitable combination of organic and inorganic $\mathrm{N}$ without affecting the potential growth and yield of baby corn in two consecutive summer and winter seasons.

\section{Materials and Methods}

\subsection{Site and Soil Conditions}

To observe the combine response of organic and inorganic $\mathrm{N}$ fertilizer on baby corn a field experiment was conducted to assess the performance of the yield and yield attributing characters of baby corn. The study was established in agronomy research field of Sylhet Agricultural University. The geographical location of the site is $24^{\circ} 54^{\prime \prime}-33^{\circ} 73^{\prime \prime} \mathrm{N}$ latitude and 91 $54^{\circ}-05^{\circ} 69^{\prime \prime} \mathrm{E}$ longitude and altitude, $30 \mathrm{~m}$ above the sea level. The soil of study field was loamy texture with low $\mathrm{pH}$ (5.05), organic matter $(1.01 \%), \mathrm{N}(0.058 \%)$ content. The study was done in two consecutive seasons winter (November, 2016 to February, 2017) and summer (April, 2017 to June, 2017).

\subsection{Setup and Design}

The experiment was laid out in RCBD design with four replications during each season. The size of experimental unit was $2.0 \mathrm{~m} \times 1.5 \mathrm{~m}$. Single baby corn hybrid seeds (Baby Star) were sown per hill with $50 \mathrm{~cm}$ row to row and $15 \mathrm{~cm}$ seed to seed distance. Both the experiments comprised different doses of organic manures (Cowdung) and inorganic fertilizer $(\mathrm{N})$. Five levels of combinations of Cowdung (CD) and Nitrogen were used as treatments in both winter and kharif seasons. The treatments used in the winter season were $\mathrm{T}_{1}=\mathrm{N} 0 \mathrm{~kg}+\mathrm{CD} 15 \mathrm{t} \mathrm{ha}^{-1}, \mathrm{~T}_{2}=\mathrm{N} 60 \mathrm{~kg}+$ CD $15 \mathrm{tha}^{-1}, \mathrm{~T}_{3}=\mathrm{N} 90 \mathrm{~kg}+\mathrm{CD} 10 \mathrm{tha}^{-1}, \mathrm{~T}_{4}=\mathrm{N} 120 \mathrm{~kg}+$ CD $5 \mathrm{tha}^{-1}$ and $\mathrm{T}_{5}=\mathrm{N} 150 \mathrm{~kg}+\mathrm{CD} 0 \mathrm{tha}^{-1}$ while in the summer season the treatment $\mathrm{T}_{1}=\mathrm{N} 30 \mathrm{~kg}+\mathrm{CD} 15 \mathrm{t}$ $\mathrm{ha}^{-1}$ varied and others remained same as in the winter season.

\subsection{Fertilizer Application}

The field was fertilized with $\mathrm{P}, \mathrm{K}, \mathrm{S}$ and $\mathrm{Zn}$ at the rate of $125-80-125-8 \mathrm{~kg} \mathrm{ha}^{-1}$ in the form of triple super phosphate (TSP), muriate of potash (MOP), gypsum and zinc sulphate respectively. The whole amount of $\mathrm{CD}$, TSP, MOP,
Gypsum and zinc sulphate and half of urea were incorporated in the soil at the time of final land preparation in each plot according to the experimental setup. The remaining half of urea as a source of $\mathrm{N}$ was top dressed at 30 days after emergence of seedling.

\subsection{Intercultural Operations}

Weeding was done by hand twice during the whole growing period, the first weeding was done after 15 days of sowing and the second was done after 35 days of sowing during both seasons. During winter season four irrigations were applied at 15, 30, 55 and 75 DAS while in summer only two irrigations were applied at 30 and 50 DAS. Diazinon $10 \mathrm{G}$ was used at the rate of $12 \mathrm{~kg} \mathrm{ha}^{-1}$ to control the cutworm in the crop field.

\subsection{Harvesting}

Baby cob corn was harvest at 2-3 days after silking. First harvest was done on 9-10 February 2017 in winter while on 26 June in summer manually by hand. Final harvest was done on 17-19 February of winter crop and 28 June-1 July of summer crop. During first five fresh baby corn cobs were randomly selected as per treatment from each plot for recording data on yield attributes.

\subsection{Data Collection}

The data were collected at every 15 days interval on different growth and yield contributing characteristic viz. plant population $\mathrm{m}^{-2}$, plant height, number of leaves, leaf area index, total Dry matter weight, leaf chlorophyll concentration (SPAD value), number of cobs plant ${ }^{-1}$, baby corn cob yield with husk, baby corn cob yield without husk, TSS (Brix \%), fodder or green biomass yield and biological yield $\left(\mathrm{t} \mathrm{ha}^{-1}\right)$.

\subsection{Statistical Analysis}

The statistical analysis of the data was done by using $R$ and STAR programs to find out the Analyses of Variances (ANOVA). The comparisons were made at $5 \%$ level of significance.

\section{Results}

\subsection{Plant Height}

The plant height differed within the treatment irrespective to growing period (Figure 1). The tallest plant was obtained from the treatment $\mathrm{T}_{5}$ and the shortest plant was found in the treatment $T_{1}$ where minimum nutrient dose was applied irrespective to the growing periods. 


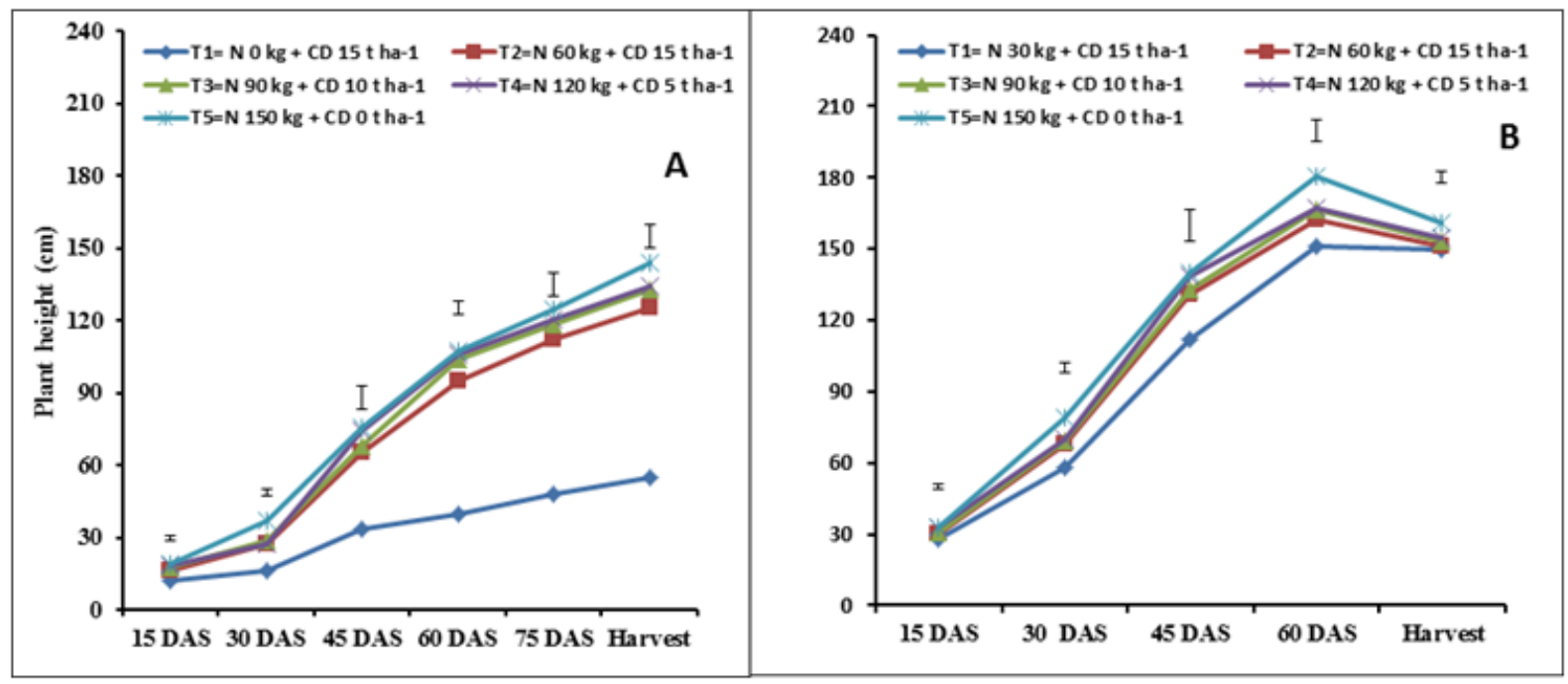

Figure 1. Plant height $(\mathrm{cm})$ at 15 days intervals during consecutive winter 2016 (A) and summer 2017 (B). Whiskers indicate individual standard deviation of the mean

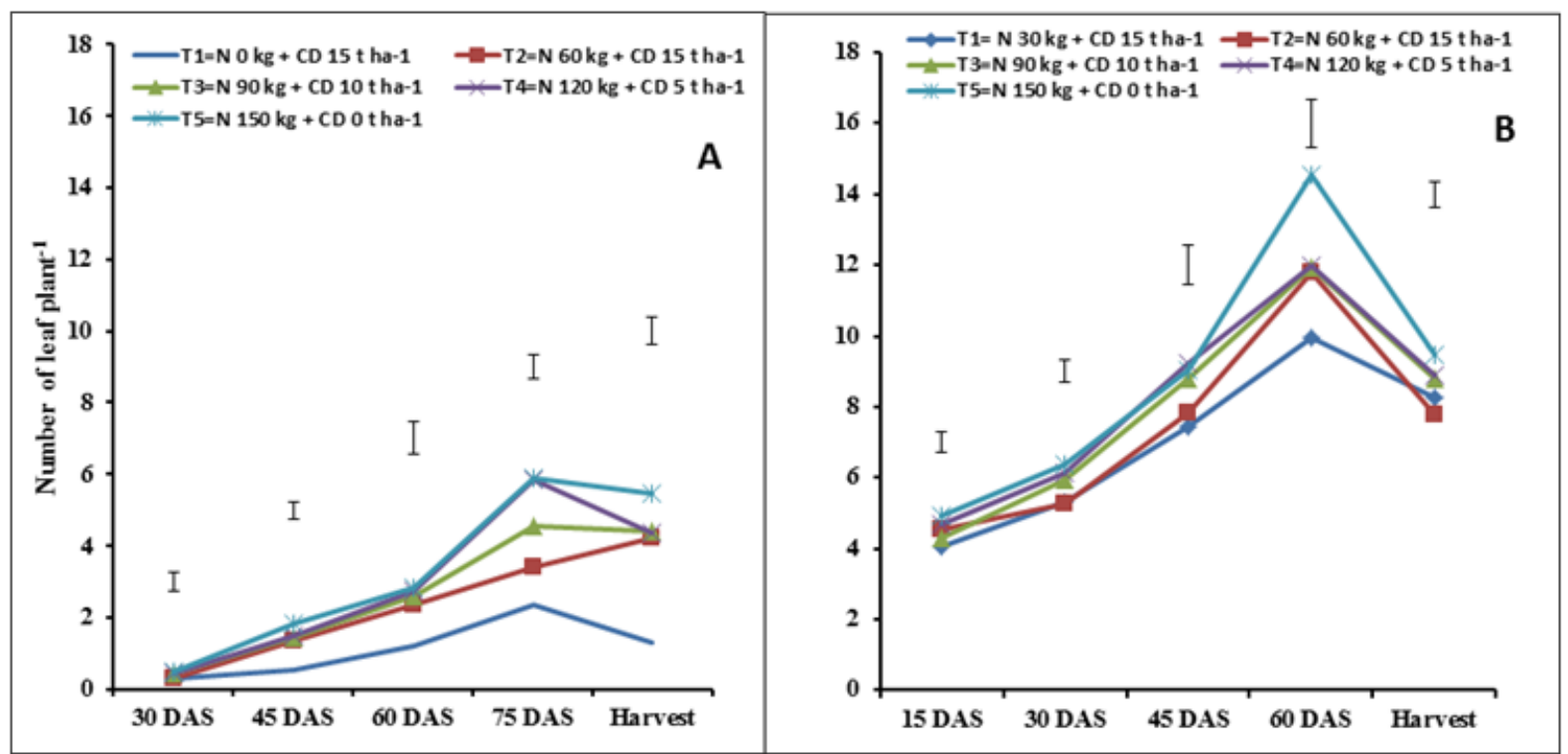

Figure 2. Number of leaf plant ${ }^{-1}$ at 15 days intervals during consecutive winter 2016 (A) and summer 2017 (B). Whiskers indicate individual standard deviation of the mean

\subsection{Number of Leaves Plant $^{-1}$}

In winter season, the results exhibited that at 15 and 30 DAS the treatment $T_{5}$ produced the highest number of leaves plant ${ }^{-1}$ which was significantly different from other treatments but at 45 and 60 DAS the treatments $\mathrm{T}_{5}$ also produced the highest number of leaves plant ${ }^{-1}$ which was statistically similar to that of $\mathrm{T}_{3}$ and $\mathrm{T}_{4}$ (Figure 2).

In summer, the highest number of leaves plant ${ }^{-1}$ was found in $\mathrm{T}_{5}$ also and it was statistically similar to $\mathrm{T}_{3}$ and $\mathrm{T}_{4}$ at 15,30 and 45 DAS. The minimum number of leaves plant ${ }^{-1}$ was found in the treatment $T_{1}$.

\subsection{Leaf Chlorophyll Concentration}

Nutrient levels significantly influenced the Soil Plant Analysis Development (SPAD) chlorophyll meter value of baby corn at all measurement dates after sowing at regular interval and at harvest during both seasons (Table 1). In winter, the highest SPAD values of $41.78,36.83$ and 34.03 were recorded from the treatment $\mathrm{T}_{5}$ at 60 DAS, 75 DAS and at harvest respectively. In summer, the results revealed that the highest SPAD values of $25.27,38.43,36.33$ and 26.20 were recorded from the treatment $\mathrm{T}_{5}$ at 15,30 and 45 DAS and at harvest respectively in summer season. It was observed that SPAD values increased with the age of the crop plants and reduced at harvest to some extent (from $7.60 \%$ to $25.17 \%$ in winter and $27.88 \%$ to $34.32 \%$ in summer). 
Table 1. SPAD values of the leaves during winter and summer (2016-2017)

\begin{tabular}{|l|l|l|l|l|l|l|l|}
\hline \multirow{2}{*}{ Treatment } & \multicolumn{4}{|c|}{ Winter } & \multicolumn{5}{c|}{ Summer } \\
\cline { 2 - 9 } & 60 DAS & 75 DAS & Harvest & 15 DAS & 30 DAS & 45 DAS & Harvest \\
\hline $\mathrm{T}_{1}$ & $19.350 \mathrm{c}$ & $22.550 \mathrm{~b}$ & $16.875 \mathrm{c}$ & $21.30 \mathrm{~b}$ & $29.00 \mathrm{~d}$ & $33.33 \mathrm{~b}$ & $21.89 \mathrm{~b}$ \\
\hline $\mathrm{T}_{2}$ & $36.300 \mathrm{~b}$ & $32.300 \mathrm{a}$ & $31.025 \mathrm{~b}$ & $22.58 \mathrm{~b}$ & $34.75 \mathrm{c}$ & $34.83 \mathrm{ab}$ & $23.03 \mathrm{ab}$ \\
\hline $\mathrm{T}_{3}$ & $36.325 \mathrm{~b}$ & $35.450 \mathrm{a}$ & $31.850 \mathrm{ab}$ & $24.25 \mathrm{a}$ & $35.83 \mathrm{bc}$ & $35.60 \mathrm{ab}$ & $23.50 \mathrm{ab}$ \\
\hline $\mathrm{T}_{4}$ & $38.900 \mathrm{~b}$ & $35.075 \mathrm{a}$ & $33.725 \mathrm{a}$ & $24.85 \mathrm{a}$ & $37.75 \mathrm{ab}$ & $35.50 \mathrm{ab}$ & $25.78 \mathrm{a}$ \\
\hline $\mathrm{T}_{5}$ & $41.775 \mathrm{a}$ & $36.825 \mathrm{a}$ & $34.025 \mathrm{a}$ & $25.27 \mathrm{a}$ & $38.43 \mathrm{a}$ & $36.33 \mathrm{a}$ & $26.20 \mathrm{a}$ \\
\hline $\mathrm{F}$ & $* * *$ & $* * *$ & $* * *$ & $* * *$ & $* * *$ & $*$ & $*$ \\
\hline
\end{tabular}

* indicates significant treatment differences $(\mathrm{p}<0.05)$

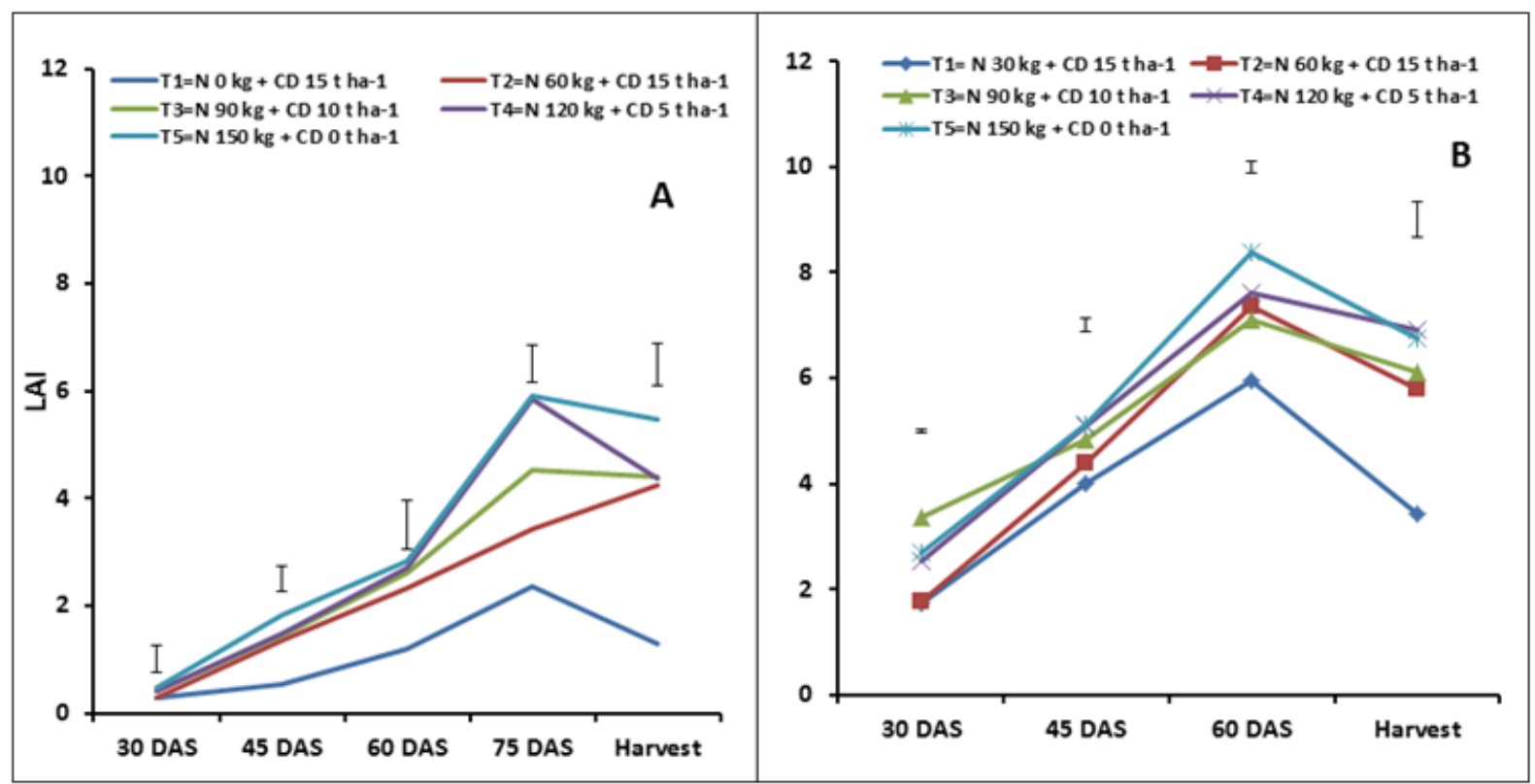

Figure 3. Leaf Area Index (LAI) at 15 days intervals during consecutive winter 2016 (A) and summer 2017 (B). Whiskers indicate individual standard deviation of the mean

\subsection{Leaf Area Index (LAI)}

The results presented that LAI at 30, 45, 60 and 75 DAS and at harvest differed significantly at different levels of nutrients in both seasons (Figure 3$)$. The treatment $\mathrm{T}_{5}(\mathrm{~N}$ $150 \mathrm{~kg}+$ Cowdung $0 \mathrm{tha}^{-1}$ ) had the highest value of LAI at all dates of measurement except at harvest during summer. LAI increased sharply as the nutrient levels as well as the age of the crop plants increased. The treatment $T_{1}$ had the lowest LAI values throughout the intervals irrespective to growing period.

\subsection{Total Dry Matter (TDM) (G Plant $\left.{ }^{-1}\right)$}

TDM of baby corn differed significantly at all sampling dates as the age of the plant increased during both the seasons (Table 2) irrespective of nutrient levels. The lowest TDM was found in the treatment $T_{1}$ during both the seasons and dry matter accumulation increased with increasing levels of nutrient. The highest TDM of 1.68, 4.11, 17.67, 23.10 and 49.67 g plant $^{-1}$ was found in the treatment $T_{5}$ at 30 45, 60 and 75 DAS and at harvest stage respectively in winter season.

\subsection{Number of Cob Plant ${ }^{-1}$}

Nutrient levels produced significant effects on the number of cob plant ${ }^{-1}$ in both seasons (Table 3 ). In winter, the highest number of cob 2.33 plant $^{-1}$ was recorded from $\mathrm{T}_{5}$ which is statistically similar with $\mathrm{T}_{4}$ of 2.20 cob plant ${ }^{-1}$. The lowest number of cob 0.33 plant $^{-1}$ was recorded from the treatment $T_{1}$. In summer, number of cob plant ${ }^{-1}$ increased significantly up to the $T_{5}(1.99)$ that is statistically similar with $\mathrm{T}_{4}$ and lowest number of cob 1.11 plant $^{-1}$ was found in the level. 
Table 2. Total dry matter (TDM) plant ${ }^{-1}$ of baby corn at 15-day intervals during winter and summer (2016-2017)

\begin{tabular}{|c|c|c|c|c|c|c|c|c|c|}
\hline \multirow{3}{*}{ Treatment } & \multicolumn{9}{|c|}{ TDM (g plant $\left.{ }^{-1}\right)$} \\
\hline & \multicolumn{4}{|c|}{ Winter } & \multicolumn{5}{|c|}{ Winter } \\
\hline & $\begin{array}{c}30 \\
\text { DAS }\end{array}$ & $\begin{array}{c}45 \\
\text { DAS }\end{array}$ & $\begin{array}{c}60 \\
\text { DAS }\end{array}$ & 75 DAS & Harvest & $\begin{array}{c}30 \\
\text { DAS }\end{array}$ & $\begin{array}{c}45 \\
\text { DAS }\end{array}$ & $\begin{array}{c}60 \\
\text { DAS }\end{array}$ & Harvest \\
\hline $\mathrm{T}_{1}$ & $0.21 \mathrm{~d}$ & $2.33 \mathrm{c}$ & $3.76 \mathrm{~d}$ & $5.58 \mathrm{c}$ & $4.84 \mathrm{~d}$ & $3.00 \mathrm{c}$ & $10.89 \mathrm{c}$ & $16.98 \mathrm{~d}$ & $38.59 \mathrm{a}$ \\
\hline $\mathrm{T}_{2}$ & $1.08 \mathrm{c}$ & $3.39 \mathrm{~b}$ & $10.97 \mathrm{c}$ & $15.82 \mathrm{~b}$ & $26.21 \mathrm{c}$ & $2.36 \mathrm{c}$ & $14.83 \mathrm{ab}$ & $22.82 \mathrm{c}$ & $32.39 \mathrm{~b}$ \\
\hline $\mathrm{T}_{3}$ & $1.44 \mathrm{ab}$ & $4.52 \mathrm{a}$ & $12.86 \mathrm{~b}$ & $23.56 \mathrm{a}$ & $38.15 b$ & $4.86 \mathrm{~b}$ & $15.62 \mathrm{a}$ & $15.96 \mathrm{~d}$ & $33.67 \mathrm{~b}$ \\
\hline $\mathrm{T}_{4}$ & $1.27 \mathrm{bc}$ & $4.43 \mathrm{a}$ & $14.24 \mathrm{~b}$ & $23.07 \mathrm{a}$ & $38.28 \mathrm{~b}$ & $6.81 \mathrm{a}$ & $13.98 \mathrm{~b}$ & $26.72 a$ & $33.36 \mathrm{~b}$ \\
\hline $\mathrm{T}_{5}$ & $1.68 \mathrm{a}$ & $4.11 \mathrm{ab}$ & $17.67 \mathrm{a}$ & $23.10 \mathrm{a}$ & $49.67 \mathrm{a}$ & $3.08 \mathrm{c}$ & $15.51 \mathrm{a}$ & $24.17 \mathrm{~b}$ & $39.38 \mathrm{a}$ \\
\hline $\mathrm{F}$ & $* * *$ & $* * *$ & $* * *$ & $* * *$ & $* * *$ & $* * *$ & $* * *$ & $* * *$ & $* * *$ \\
\hline
\end{tabular}

Table 3. Yield attributes and yields of baby corn as influenced by organic and inorganic $\mathrm{N}$ during winter and summer (2016-2017)

\begin{tabular}{|c|c|c|c|c|c|c|c|}
\hline \multirow{2}{*}{ Treatment } & \multicolumn{2}{|c|}{ CPP } & \multicolumn{2}{c|}{ CY* } & \multicolumn{2}{c|}{ CY** } & TSS (\%) \\
\cline { 2 - 8 } & $\mathrm{W}$ & $\mathrm{S}$ & $\mathrm{W}$ & $\mathrm{S}$ & $\mathrm{W}$ & $\mathrm{S}$ & $\mathrm{S}$ \\
\hline $\mathrm{T}_{1}$ & $0.30 \mathrm{c}$ & $1.11 \mathrm{~d}$ & $0.68 \mathrm{~d}$ & $5.07 \mathrm{c}$ & $0.13 \mathrm{~d}$ & $0.75 \mathrm{~d}$ & $10.00 \mathrm{a}$ \\
\hline $\mathrm{T}_{2}$ & $1.78 \mathrm{~b}$ & $1.49 \mathrm{c}$ & $7.84 \mathrm{c}$ & $7.46 \mathrm{~b}$ & $1.36 \mathrm{c}$ & $1.15 \mathrm{c}$ & $8.25 \mathrm{c}$ \\
\hline $\mathrm{T}_{3}$ & $1.93 \mathrm{~b}$ & $1.72 \mathrm{~b}$ & $9.69 \mathrm{~b}$ & $8.19 \mathrm{~b}$ & $1.78 \mathrm{~b}$ & $1.38 \mathrm{~b}$ & $9.75 \mathrm{ab}$ \\
\hline $\mathrm{T}_{4}$ & $2.20 \mathrm{a}$ & $1.95 \mathrm{a}$ & $11.19 \mathrm{a}$ & $9.34 \mathrm{a}$ & $2.06 \mathrm{a}$ & $1.64 \mathrm{a}$ & $8.75 \mathrm{bc}$ \\
\hline $\mathrm{T}_{5}$ & $2.33 \mathrm{a}$ & $1.99 \mathrm{a}$ & $11.56 \mathrm{a}$ & $9.54 \mathrm{a}$ & $2.13 \mathrm{a}$ & $1.72 \mathrm{a}$ & $8.50 \mathrm{c}$ \\
\hline $\mathrm{F}$ & $* * *$ & $* * *$ & $* * *$ & $* * *$ & $* * *$ & $* * *$ & $* *$ \\
\hline
\end{tabular}

Note: $\mathrm{CPP}=$ Number of cob plant ${ }^{-1} ; \mathrm{CY}^{*}=\mathrm{Cob}$ yield $\left(\mathrm{t} \mathrm{ha}^{-1}\right)$ with husk; $\mathrm{CY}^{* *}=\mathrm{Cob}$ yield $\left(\mathrm{t}^{-1} \mathrm{a}^{-1}\right)$ without husk, $\mathrm{TSS}=$ sugar content

\subsection{Cob Yield with and without Husk}

Cob yield without husk differed significantly in variation of nutrients applied in winter (Table 3). During winter, cob yield with husk increased sharply up to the $T_{4}$ $\left(11.19 \mathrm{t} \mathrm{ha}^{-1}\right)$ and beyond the level at $\mathrm{T}_{5}\left(11.56 \mathrm{tha}^{-1}\right)$ yield increment was insignificant while lowest from $T_{1}(0.68 \mathrm{t}$ $\left.\mathrm{ha}^{-1}\right)$. In summer, the highest cob yield was noted in $\mathrm{T}_{5}$ $\left(9.54 \mathrm{tha}^{-1}\right)$, whereas the lowest from $\mathrm{T}_{1}\left(5.07 \mathrm{t} \mathrm{ha}^{-1}\right)$ with significantly different from other treatments.

Cob yield without husk showed noteworthy upward trend with increased nutrient level up to $\mathrm{T}_{4}$ in both seasons (Table 3). The highest cob yield without husk in winter and summer was recorded in $\mathrm{T}_{5}\left(2.13 \mathrm{t} \mathrm{ha}^{-1}, 1.72 \mathrm{t} \mathrm{ha}^{-1}\right.$ respectively) which was statistically similar with $T_{4}$ whereas minimum in $\mathrm{T}_{1}$.

\subsection{Fodder Yield}

Fodder yield of baby corn significantly differed for different nutrient levels (Figure 4) in both seasons. There was sharp increment up to $T_{4}$ in winter while $T_{3}$ in summer. In winter, the highest fodder yield was recorded from $T_{5}$ $\left(15.55 \mathrm{t} \mathrm{ha}^{-1}\right)$ which was statistically similar with $\mathrm{T}_{4}(15.33$ $\left.\mathrm{t} \mathrm{ha}^{-1}\right)$ whereas lowest fodder yield in $\mathrm{T}_{1}\left(3.11 \mathrm{t} \mathrm{ha}^{-1}\right)$. In summer, the highest fodder yield was obtained from $T_{5}$ $\left(20.36 \mathrm{t} \mathrm{ha}^{-1}\right)$ which was statistically similar to that of $\mathrm{T}_{3}$ and $\mathrm{T}_{4}$ (19.88 and $20.00 \mathrm{tha}^{-1}$ respectively). 


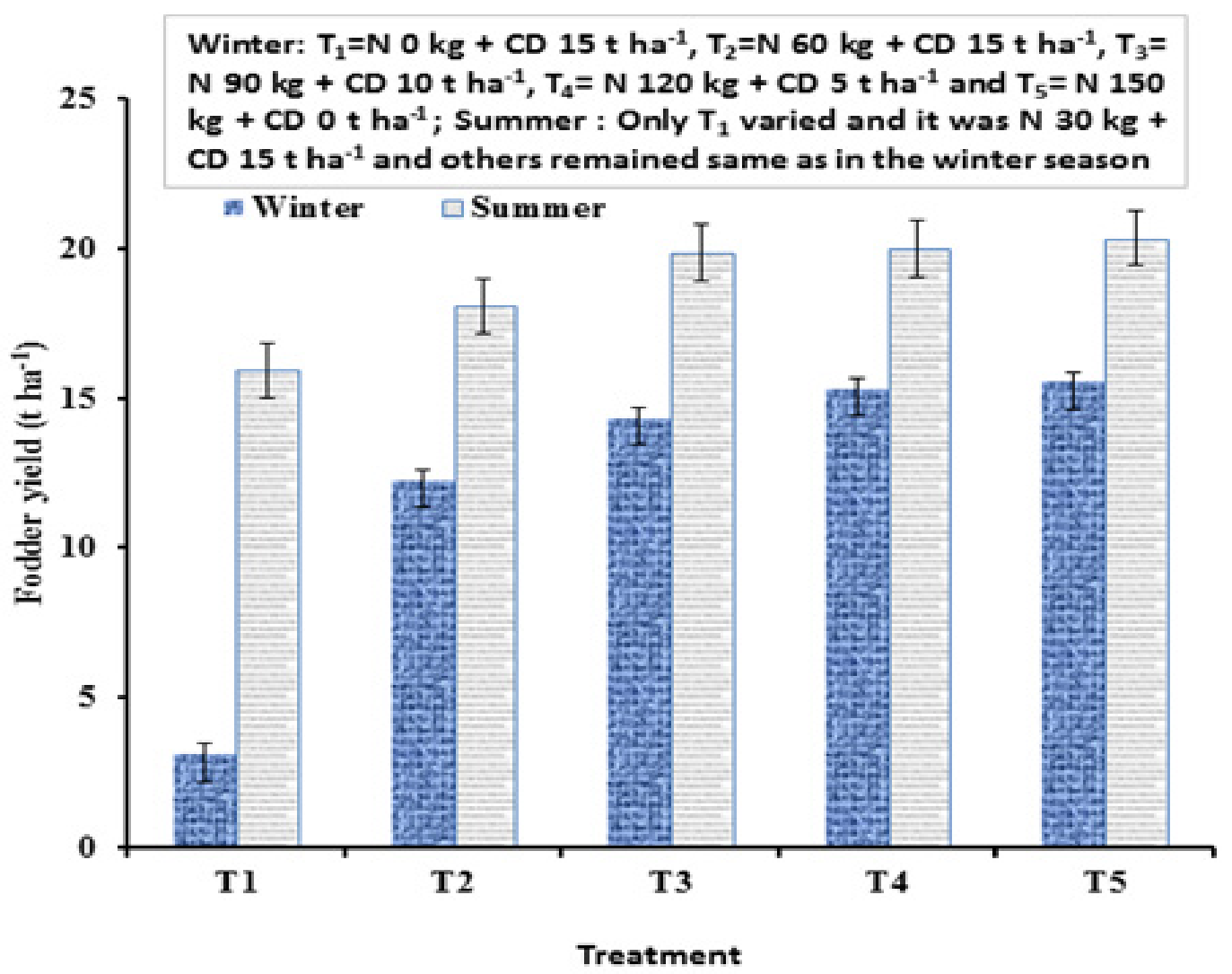

Figure 4. Fodder yield of corn in winter and summer seasons. Whiskers indicate individual standard deviation of the mean

\subsection{Combined Analysis}

The treatment $\mathrm{T}_{1}$ showed variation in winter and summer only in terms of inorganic $\mathrm{N}$ while the remaining treatments were same. Therefore, the combined analysis was done excluding the $T_{1}$.

\subsubsection{Season Effects}

There was a significant difference between two growing seasons in terms of different growth and yield contributing characters (Table 4). Except plant height all the parameters were found higher in winter season. However, no significant disparity was found for cob length with husk and cob diameter without husk. It was found that about $1.67 \%$ higher cob yield with husk $\left(10.07 \mathrm{t} \mathrm{ha}^{-1}\right)$ and $0.25 \%$ higher cob yield without husk $\left(1.84 \mathrm{tha}^{-1}\right)$ was produced in the winter season compared to summer.

\subsubsection{Effect of Nutrient Levels}

From the combined analysis significant differences among the treatments in terms of parameters studied except days to silking and days to final harvest (Table 5). The treatment $T_{5}$ had the tallest plant of $142.78 \mathrm{~cm}$ while the shortest one of $131.68 \mathrm{~cm}$ was noted in $T_{2}$. Ear height did not increase significantly beyond the $\mathrm{T}_{3}$ and the highest ear height was found in $\mathrm{T}_{4}(70.18 \mathrm{~cm})$. Similar trend like ear height was found for cob length with husk. The highest cob length without husk was found in $\mathrm{T}_{5}(9.64 \mathrm{~cm})$ that was similar to $T_{4}(9.11 \mathrm{~cm})$ while the number of cob plant ${ }^{-1}$ did not enhance away from the treatment $\mathrm{T}_{4}(2.07)$ which was statistically similar with $\mathrm{T}_{5}(2.16)$. Cob yield with husk was found significantly highest in the $T_{5}\left(10.55 \mathrm{t} \mathrm{ha}^{-1}\right)$ which was statistically similar with $\mathrm{T}_{4}\left(10.27 \mathrm{tha}^{-1}\right)$ while lowest in the $T_{2}\left(7.65 \mathrm{t} \mathrm{ha}^{-1}\right)$. Similar trend like cob yield with husk was found in case of the parameter cob yield without husk.

\subsubsection{Interaction of Growing Season and Nutrient Level}

Data presented in (Table 6) indicated that all the parameters subjected to be combined analyses differed significantly except days to silking and days to final harvest irrespective of seasons. Ear height significantly higher at all the nutrient levels during summer compared to the winter. The cob length without husk was found highest in the $T_{5}$ during winter and the lowest was noted in the $T_{2}$ during summer. Most of the values regarding this parameter of the treatments were higher during winter. Cob yield with husk was recorded significantly highest in $\mathrm{T}_{5}$ similar to that of $T_{4}$ during winter and lowest in $T_{2}$ during summer. The treatment $T_{3}$ of winter season produced statistically similar cob yield with husk to that of $T_{4}$ and $T_{5}$ of summer season. Similar trend was found for cob yield without husk. 
Table 4. Growth, yield components and cob yield of baby corn in winter and summer (2016-2017)

\begin{tabular}{|l|l|l|l|l|l|l|l|l|l|l|l|}
\hline Season & PHT & EHT & CLHSK & CLNHSK & CDNH & CPP & CY* & CY** & DS & DFH \\
\hline Winter & $119.12 \mathrm{~b}$ & $81.36 \mathrm{a}$ & $14.92 \mathrm{a}$ & $9.62 \mathrm{a}$ & 8.09 & $2.06 \mathrm{a}$ & $10.07 \mathrm{a}$ & $1.84 \mathrm{a}$ & $77.88 \mathrm{a}$ & $97.13 \mathrm{a}$ \\
\hline Summer & $155.01 \mathrm{a}$ & $52.22 \mathrm{~b}$ & $14.86 \mathrm{a}$ & $8.41 \mathrm{~b}$ & 7.92 & $1.79 \mathrm{~b}$ & $8.63 \mathrm{~b}$ & $1.47 \mathrm{~b}$ & $60.88 \mathrm{~b}$ & $70.00 \mathrm{~b}$ \\
\hline CV $(\%)$ & 4.06 & 2.99 & 7.35 & 3.71 & 7.37 & 10.05 & 5.96 & 3.20 & 1.58 & 0.80 \\
\hline F & $* * *$ & $* * *$ & $\mathrm{~ns}$ & $* * *$ & $\mathrm{~ns}$ & $* * *$ & $* * *$ & $* * *$ & $* * *$ & $* * *$ \\
\hline
\end{tabular}

Note: PHT=Plant height; EHT=Ear height; $\mathrm{CLHSK}=\mathrm{Cob}$ length with husk; $\mathrm{CLNHSK}=\mathrm{Cob}$ length without husk; $\mathrm{CDNH}=\mathrm{Cob}$ diameter without husk; $\mathrm{CPP}=$ Number of cob plant-1; $\mathrm{CY}^{*}=\mathrm{Cob}$ yield with husk; $\mathrm{CY}^{* *}=\mathrm{Cob}$ yield without husk; DS=Days to silking; DFH=Days to final harvest.

Table 5. Days to silking, days to final harvest, yield components and cob yield of baby corn as influenced by nutrient levels during winter and summer (2016-2017)

\begin{tabular}{|l|l|l|l|l|l|l|l|l|l|l|}
\hline $\begin{array}{l}\text { Nutrient } \\
\text { level }\end{array}$ & PHT & EHT & CLHSK & CLNHSK & CDNH & CPP & CY* & CY** & DS & DFH \\
\hline T2 & $131.68 \mathrm{c}$ & $60.50 \mathrm{~b}$ & $13.98 \mathrm{~b}$ & $8.68 \mathrm{~b}$ & $7.16 \mathrm{c}$ & $1.63 \mathrm{~b}$ & $7.65 \mathrm{c}$ & $1.25 \mathrm{c}$ & 69.50 & 84.00 \\
\hline T3 & $135.78 \mathrm{~b}$ & $68.49 \mathrm{a}$ & $14.68 \mathrm{ab}$ & $9.11 \mathrm{ab}$ & $8.06 \mathrm{~b}$ & $1.82 \mathrm{~b}$ & $8.94 \mathrm{~b}$ & $1.58 \mathrm{~b}$ & 69.50 & 83.50 \\
\hline T4 & $138.05 \mathrm{~b}$ & $70.18 \mathrm{a}$ & $15.51 \mathrm{a}$ & $8.64 \mathrm{~b}$ & $8.18 \mathrm{ab}$ & $2.07 \mathrm{a}$ & $10.27 \mathrm{a}$ & $1.85 \mathrm{a}$ & 69.13 & 83.50 \\
\hline T5 & $142.78 \mathrm{a}$ & $67.99 \mathrm{a}$ & $15.39 \mathrm{a}$ & $9.64 \mathrm{a}$ & $8.63 \mathrm{a}$ & $2.16 \mathrm{a}$ & $10.55 \mathrm{a}$ & $1.93 \mathrm{a}$ & 69.50 & 83.25 \\
\hline F & $* * *$ & $* * *$ & $* *$ & $*$ & $* * *$ & $* *$ & $* * *$ & $* * *$ & $\mathrm{~ns}$ & $\mathrm{~ns}$ \\
\hline
\end{tabular}

Note: $\mathrm{PHT}=$ plant height; $\mathrm{EHT}=$ Ear height; $\mathrm{CLHSK}=\mathrm{Cob}$ length with husk; $\mathrm{CLNHSK}=\mathrm{Cob}$ length without husk; $\mathrm{CDNH}=\mathrm{Cob}$ diameter without husk; $\mathrm{CPP}=$ Number of $\operatorname{cob}$ plant $^{-1} ; \mathrm{CY}^{*}=\mathrm{Cob}$ yield with husk; $\mathrm{CY}^{* *}=\mathrm{Cob}$ yield without husk; $\mathrm{DS}=$ Days to silking; $\mathrm{DFH}=$ Days to final harvest.

Table 6. Interaction of season and nutrient levels on the growth, yield components and yield of baby corn during winter and summer (2016-2017)

\begin{tabular}{|l|l|l|l|l|l|l|l|l|l|l|}
\hline $\mathrm{S} \times$ N level & PHT & EHT & CLHSK & CLNHSK & CDNH & CPP & CY* & CY** & DS & DFH \\
\hline $\mathrm{WT}_{2}$ & $112.30 \mathrm{e}$ & $41.55 \mathrm{c}$ & $13.5 \mathrm{c}$ & $9.73 \mathrm{ab}$ & $7.25 \mathrm{~d}$ & $1.78 \mathrm{~cd}$ & $7.84 \mathrm{c}$ & $1.35 \mathrm{c}$ & 77.75 & 96.75 \\
\hline $\mathrm{WT}_{3}$ & $118.20 \mathrm{~d}$ & $5.58 \mathrm{~b}$ & $14.63 \mathrm{bc}$ & $9.15 \mathrm{bc}$ & $7.75 \mathrm{bcd}$ & $1.93 \mathrm{bc}$ & $9.69 \mathrm{~b}$ & $1.78 \mathrm{~b}$ & 77.75 & 97.00 \\
\hline $\mathrm{WT}_{4}$ & $121.20 \mathrm{~cd}$ & $58.0 \mathrm{~b}$ & $16.18 \mathrm{a}$ & $9.08 \mathrm{bcd}$ & $8.38 \mathrm{ab}$ & $2.20 \mathrm{ab}$ & $11.19 \mathrm{a}$ & $2.06 \mathrm{a}$ & 77.50 & 97.25 \\
\hline $\mathrm{WT}_{5}$ & $124.80 \mathrm{c}$ & $53.75 \mathrm{~b}$ & $15.10 \mathrm{ab}$ & $10.55 \mathrm{a}$ & $9.00 \mathrm{a}$ & $2.33 \mathrm{a}$ & $11.56 \mathrm{a}$ & $2.13 \mathrm{a}$ & 78.50 & 97.50 \\
\hline $\mathrm{ST}_{2}$ & $151.05 \mathrm{~b}$ & $79.45 \mathrm{a}$ & $14.43 \mathrm{bc}$ & $7.63 \mathrm{e}$ & $7.07 \mathrm{~d}$ & $1.49 \mathrm{~d}$ & $7.46 \mathrm{c}$ & $1.15 \mathrm{~d}$ & 61.00 & 69.75 \\
\hline $\mathrm{ST}_{3}$ & $153.35 \mathrm{~b}$ & $81.40 \mathrm{a}$ & $14.73 \mathrm{bc}$ & $9.08 \mathrm{bcd}$ & $8.38 \mathrm{ab}$ & $1.72 \mathrm{~cd}$ & $8.19 \mathrm{c}$ & $1.38 \mathrm{c}$ & 61.25 & 70.00 \\
\hline $\mathrm{ST}_{4}$ & $154.90 \mathrm{~b}$ & $82.22 \mathrm{a}$ & $14.85 \mathrm{~b}$ & $8.20 \mathrm{de}$ & $8.00 \mathrm{bc}$ & $1.95 \mathrm{bc}$ & $9.34 \mathrm{~b}$ & $1.64 \mathrm{~b}$ & 60.75 & 69.75 \\
\hline $\mathrm{ST}_{5}$ & $160.75 \mathrm{a}$ & $82.38 \mathrm{a}$ & $15.68 \mathrm{ab}$ & $8.73 \mathrm{~cd}$ & $8.25 \mathrm{ab}$ & $1.99 \mathrm{bc}$ & $9.54 \mathrm{~b}$ & $1.72 \mathrm{~b}$ & 60.50 & 70.50 \\
\hline $\mathrm{F}$ & $*$ & $* *$ & $*$ & $*$ & $*$ & $*$ & $*$ & $*$ & $\mathrm{~ns}$ & $\mathrm{~ns}$ \\
\hline
\end{tabular}

Note: $\mathrm{S}=$ Summer, $\mathrm{N}=$ Nutrient, $\mathrm{PHT}=$ plant height; $\mathrm{EHT}=$ Ear height; $\mathrm{CLHSK}=$ Cob length with husk; $\mathrm{CLNHSK}=$ Cob length without husk; $\mathrm{CDNH}=\mathrm{Cob}$ diameter without husk; $\mathrm{CPP}=$ Number of $\operatorname{cob}$ plant $^{-1} ; \mathrm{CY}^{*}=$ Cob yield with husk; $\mathrm{CY}^{* *}=\mathrm{Cob}$ yield without husk; DS=Days to silking; $\mathrm{DFH}=$ Days to final harvest

\section{Discussion}

The result of this study revealed that the influence of the combination of different levels of inorganic and organic $\mathrm{N}$ sources significantly affect the growth and yield parameters of baby corn.

\subsection{Response of Growth Parameters}

In general, the treatment with higher $\mathrm{N}$ level in different ages showed higher plant height and number of leaves plant $^{-1}$. $\mathrm{N}$ fertilization increase plant height of corn (Onasanya et al. [25]; Asaduzzaman et al. [4]) as $\mathrm{N}$-fertilizer enhances the growth of a crop plant through synthesizing more protein and chlorophyll (Zhao et al. [31]). Besides, $\mathrm{N}$ fertilizer provides energy for microbial activities in order to mineralize the organic nitrogen of organic manure and makes it available to crop (Rashid et al.
[27]). The result also expressed that the number of leaves plant $^{-1}$ increased with increasing plant age as well as nutrient level and reduced at harvest than the earlier dates of measurement. It may be due to the development of senescence of the older leaves (Thomas [29]). The increased LAI might be due to the increased availability of $\mathrm{N}$ under the higher levels of organic manure and inorganic fertilizers which ensured enough $\mathrm{N}$ to produce the number of leaves with the larger size (Amanullah et al. [2]). The leaf chlorophyll content showed increasing trend with increasing $\mathrm{N}$ supply. The chlorophyll content of leaves is positively correlated with availability of nitrogen in soil (Bojović \& Marković [5]). Lower chlorophyll content of leaf at the harvesting stage might have been due to remobilization of $\mathrm{N}$ from leaves to reproductive organs as cob formation (Ghildiyal \& Sirohi [10]). TDM increased progressively with the progressive increase in nutrient 
levels and the value attained peak at harvesting stage. The DM production was largely a function of photosynthetic surface, which was favorably influenced by $\mathrm{N}$-fertilization. Previous few researches revealed positive correlation between $\mathrm{N}$ rates and dry matter yield in maize (Greef et al. [14]; Amanullah et al. [2]).

Besides, plants represented better performance in terms of plant height and number of leaves plant ${ }^{-1}$ in the summer than winter. In terms of season, temperature is one of the key factors affecting the rate of plant growth and development. During summer the air and soil temperature is higher than winter. Higher soil temperature increases the activity of soil microbes leading to availability of plant nutrients in soil ( $\mathrm{Lu} \& \mathrm{Xu}[22])$. Besides, in summer season plant receive direct sunlight leads to create more photosynthate and increase plant and ear height, chlorophyll content and LAI (Hart [16]; González-Sanpedro et al. [12]; Amanullah et al. [1]).

\subsection{Yield Contributing Characters and Yield}

The yield contributing characters, grain and fodder yield of baby corn also influenced by different levels of $\mathrm{N}$ fertilization and season. The performance of yield contributing characters and yield found higher in winter season. However, fodder yield found higher in summer. In terms of $\mathrm{N}$ fertilization level, although $\mathrm{T}_{5}(\mathrm{~N} 150 \mathrm{~kg}+\mathrm{CD} 0$ $\left.t \mathrm{tha}^{-1}\right)$ represented better output, no statistical differences with $\mathrm{T}_{4}\left(\mathrm{~N} 120 \mathrm{~kg}+\mathrm{CD} 5 \mathrm{tha}^{-1}\right)$. A rapid growth in higher level of nitrogen fertilization might have played a significant role in reducing competition for photosynthates and nutrients with neighbor. The available photosynthates might have influence the number of flowers and their fertilization which ultimately ensure higher yield attributes. The positive correlation of grain yield and yield attributes to higher nitrogen fertilization corroborate findings of several previous researches (Chillar \& Kumar [6]; Gosavi \& Bhagat [13]; Golada et al. [11]). The increased fodder yield with higher $\mathrm{N}$ fertilization was also recorded by some researchers (Gosavi \& Bhagat [13]; Gulabrao [15]). As the result revealed that most of the growth parameters such as plant height, number of leaf number plant ${ }^{-1}$ was higher which finally produced higher fodder yield in summer.

There were some fluxions in the growth parameters especially in the early stages of their life cycle. The treatment with lower inorganic and organic $\mathrm{N}$ ratio displayed better performance. This is may be due to mineralization of $\mathrm{N}$ from cowdung was slow enough to supply adequate necessary $\mathrm{N}$ in early stage of plant. However, it did not exhibit its impact on yield severely. Therefore, our result revealed that $20 \%$ minimization of inorganic $\mathrm{N}$ is possible for baby corn production in integration of organic $\mathrm{N}$ (cowdung) source.

\section{Conclusions}

To investigate the response of baby corn the present study was conducted in combination of inorganic and organic $\mathrm{N}$ in order to reduce inorganic $\mathrm{N}$ supply without hindering maximum output in summer and winter seasons. Among the five nutrient levels the integration of 5 tons of $\mathrm{CD}$ along with $120 \mathrm{~kg}$ inorganic $\mathrm{N} \mathrm{ha}^{-1}$ showed the best results with respect to yield and quality parameters. The nutrient level $120 \mathrm{~kg} \mathrm{~N}+5 \mathrm{t} \mathrm{CD} \mathrm{ha}^{-1}$ gave baby corn yield statistically similar to that of $150 \mathrm{~kg} \mathrm{~N}+0 \mathrm{tCD} \mathrm{ha}{ }^{-1}$ having the highest yield during both seasons. Nutrient level of 120 $\mathrm{kg} \mathrm{N}+5 \mathrm{t} \mathrm{CD} \mathrm{ha}{ }^{-1}$ on account of having significant effect on growth and yield parameters of baby corn, can be recommended for higher baby corn yield along with maintaining and sustaining soil health and reducing environment pollution for future generation as well as improving the economic stability of the farmers than sole use of either chemical fertilizers or organic manures.

\section{REFERENCES}

[1] Amanullah H, Marwat KB, Shah P, Maula N and Arifullah S. Nitrogen levels and its time of application influence leaf area, height and biomass of maize planted at low and high density. Pakistan Journal of Botany. 41:761-768, 2009.

[2] Amanullah MJH, Nawab K and Ali A. Response of specific leaf area (SLA), leaf area index (LAI) and leaf area ratio (LAR) of maize (Zea mays L.) to plant density, rate and timing of nitrogen application. World Applied Sciences Journal. 2:235-243, 2007.

[3] Archana CR and Bai EKL. Influence of varieties and spacing on yield of dual purpose baby corn (Zea mays L.) in summer rice fallows of Kerala. Journal of Tropical Agriculture. 54:190, 2017.

[4] Asaduzzaman M, Biswas M, Islam MN, Rahman MM, Begum R and Sarkar MAR. Variety and N-fertilizer rate influence the growth, yield and yield parameters of baby corn (Zea mays L.). Journal of Agricultural Science. 6:118, 2014.

[5] Bojović B and Marković A. Correlation between nitrogen and chlorophyll content in wheat (Triticum aestivum L.). Kragujevac Journal of Science. 31:69-74, 2009.

[6] Chillar RK and Kumar A. Growth and yield behaviour of sweet corn (Zea mays L. saccharata) under varying plant population and nitrogen level. In: Extended Summaries of Golden Jubilee National Symposium on conservation Agriculture and Environment. India: Hindawi Publishing Corporation; p. 277-278, 2006.

[7] Dadarwal R. Integrated nutrient management in baby corn (Zea mays L.). Udaipur: Maharana Pratap University of Agriculture and Technology. 2008.

[8] Das S, Ghosh G, Kaleem MD and Bahadur V. Effect of different levels of nitrogen and crop geometry on the growth, yield and quality of baby corn (Zea mays L.) cv.'golden baby'. In: International Symposium on the Socio-Economic Impact of Modern Vegetable Production Technology in Tropical Asia 809. Chiang Mai, Thailand; p. 161-166, 2008. 
[9] Dawe D, Dobermann A, Ladha JK, Yadav RL, Bao L, Gupta RK, Lal P, Panaullah G, Sariam O and Singh Y. Do organic amendments improve yield trends and profitability in intensive rice systems? Field Crops Research. 83:191-213, 2003.

[10] Ghildiyal MC and Sirohi GS. Nitrogen-utilization during growth and development in mungbean. Indian Journal of Experimental Biology. 24:124-126, 1986.

[11] Golada SL, Sharma GL and Jain HK. Performance of baby corn (Zea mays L.) as influenced by spacing, nitrogen fertilization and plant growth regulators under sub humid condition in Rajasthan, India. African Journal of Agricultural Research. 8:1100-1107, 2013.

[12] González-Sanpedro MC, Le Toan T, Moreno J, Kergoat L and Rubio E. Seasonal variations of leaf area index of agricultural fields retrieved from Landsat data. Remote Sensing of Environment. 112:810-824, 2008.

[13] Gosavi SP and Bhagat SB. Effect of nitrogen levels and spacing on yield attributes, yield and quality parameters of baby corn (Zea mays). Annals of Agricultural Research. 30, 2009.

[14] Greef JM, Ott H, Wulfes R and Taube F. Growth analysis of dry matter accumulation and $\mathrm{N}$ uptake of forage maize cultivars affected by $\mathrm{N}$ supply. The Journal of Agricultural Science. 132:31-43, 1999.

[15] Gulabrao SK. Response of baby corn (Zea mays) to plant density and fertilizers levels. 2010.

[16] Hart JW. Light and plant growth. Unwin Hyman, London.: Springer Science \& Business Media. 1988.

[17] Henrique Demari G, Carvalho I, Nardino M, Szareski V, Morgan Dellagostin S, Corazza da Rosa T, Follmann D, Andrade Monteiro M, Basso J, Pedó $\mathrm{T}$ and Tiago $\mathrm{Z}$. Importance of nitrogen in maize production. International journal of Current Research. 8:36629-36634, 2016.

[18] Kitchen NR and Goulding KWT. On-farm technologies and practices to improve nitrogen use efficiency. In: Nitrogen in the environment: sources, problems and management. In R.F. ronmental benefits. Follett and J.L. Hatfield (ed.) Nitrogen in the environment: Sources, problems, and management. C4 Amster- Spatial patterns of variability in EONR have implica- dam, the Netherlands.: Elsevier; p. 335-369, 2001.

[19] Kumar R and Bohra JS. Effect of NPKS and Zn application on growth, yield, economics and quality of baby corn. Archives of Agronomy and Soil Science. 60:1193-1206, 2014.

[20] Lara MV and Andreo CS. C4 plants adaptation to high levels of $\mathrm{CO}_{2}$ and to drought environments. In: Abiotic Stress in Plants-Mechanisms and Adaptations In A Shanker (Ed), Abiotic stress in plants - mechanisms and adaptations. Croatia: InTech; p. 415-428, 2011.

[21] Lone AA, Allai BA and Nehvi FA. Growth, yield and economics of baby corn (Zea mays L.) as influenced by Integrated Nutrient Management (INM) practices. African Journal of Agricultural Research. 8:4537-4540, 2013.

[22] Lu Y and Xu H. Effects of Soil Temperature, Flooding, and Organic Matter Addition on $\mathrm{N}_{2} \mathrm{O}$ Emissions from a Soil of
Hongze Lake Wetland, China. The Scientific World Journal. 2014.

[23] Mahmoodi, S., Rahimi, A. Estimation of critical period of weed control in corn in Iran. Weed Acad. Sci., 49: 67-72, 2009 .

[24] Muhammad S, Fathelrahman E and Tasbih Ullah RU. The significance of consumer's awareness about organic food products in the United Arab Emirates. Sustainability. 8:833, 2016.

[25] Onasanya RO, Aiyelari OP, Onasanya A, Oikeh S, Nwilene $\mathrm{FE}$ and Oyelakin OO. Growth and yield response of maize (Zea mays L.) to different rates of nitrogen and phosphorus fertilizers in southern Nigeria. World Journal of Agricultural Sciences. 5:400-407, 2009.

[26] Pang XP and Letey J. Organic farming challenge of timing nitrogen availability to crop nitrogen requirements. Soil Science Society of America Journal. 64:247-253, 2000.

[27] Rashid MI, Mujawar LH, Shahzad T, Almeelbi T, Ismail IMI and Oves M. Bacteria and fungi can contribute to nutrients bioavailability and aggregate formation in degraded soils. Microbiological Research. 183:26-41, 2016.

[28] Thavaprakaash N, Velayudham K and Muthukumar VB. Effect of crop geometry, intercropping systems and integrated nutrient management practices on productivity of baby corn (Zea mays L.) based intercropping systems. Research Journal of Agricultural and Biological Sciences. $1: 295-302,2005$.

[29] Thomas H. Senescence, ageing and death of the whole plant. New Phytologist. 197:696-711, 2013.

[30] Timsina J. 2018. Can Organic Sources of Nutrients Increase Crop Yields to Meet Global Food Demand? Agronomy. 8:214, 2018.

[31] Zhao D, Reddy KR, Kakani VG and Reddy VR. Nitrogen deficiency effects on plant growth, leaf photosynthesis, and hyperspectral reflectance properties of sorghum. European Journal of Agronomy. 22:391-403, 2005. 